\title{
Zróżnicowanie facjalne glin jako wskaźnik fluktuacji ciśnienia wód subglacjalnych na kontakcie lodu i podłoża podczas zlodowacenia wisły w północnej części Pojezierza Dobrzyńskiego
}

\author{
Till facies diversity as an indicator of subglacial water pressure fluctuations at the ice/bed \\ interface during Weichselian glaciation in N part of Dobrzyń Lakeland
}

\author{
Włodzimierz Narloch1, Justyna M. Wojciechowska ${ }^{1}$, Alicja Osowicka1', Wojciech Wysota1, \\ Jan A. Piotrowski ${ }^{2}$, Marcin Sobiech ${ }^{1}$ \\ ${ }^{1}$ Katedra Geologii i Hydrogeologii, Uniwersytet Mikołaja Kopernika,Toruń,w.narloch@umk.pl \\ ${ }^{2}$ Department of Geoscience, Aarhus University, Dania
}

\begin{abstract}
Zarys treści: Badaniom sedymentologicznym poddano gliny lodowcowe fazy poznańskiej zlodowacenia wisły na dwóch stanowiskach terenowych (Przeszkoda i Obórki), zlokalizowanych w północnej części Pojezierza Dobrzyńskiego. Podczas ostatniego zlodowacenia obszar ten był pokryty lobem lodowcowym Wisły, którego rozwój był najprawdopodobniej determinowany przez wiślany strumień lodowy. W rekonstrukcji procesów formowania glin oraz mechanizmów ruchu lodu została zastosowana kompleksowa analiza glin, w tym: cech sedymentacyjnych, uziarnienia, składu petrograficznego, orientacji dłuższej osi głazików oraz analiza mikromorfologiczna. Analizowane gliny są masywne i warstwowane. Badania sugerują występowanie złożonych i czasowo zmiennych warunków pod lobem Wisły, prawdopodobnie spowodowanych przez fluktuacje ciśnienia wód subglacjalnych. Ruch lodu był wynikiem kombinacji deformacji podłoża i poślizgu bazalnego.
\end{abstract}

Slowa kluczowe: glina subglacjalna, poślizg bazalny, deformacja podłoża, Pojezierze Dobrzyńskie

\begin{abstract}
Sedimentological analyses were performed on glacial till of the Weichselian glaciation in two field sites (Przeszkoda and Obórki) which are located in northern part of the Dobrzyń Lakeland. During the last glaciation this area was covered by the Vistula ice lobe which development has been determined by the Vistula Ice Stream. A multi-proxy approach including a study of sedimentary features, grain size, petrographic composition, till fabric and till micromorphology was used in reconstruction of till formation and ice movement mechanisms. Analysed tills are massive and stratified. We suggest existing of complex and temporally variable conditions under the Vistula ice lobe, probably caused by subglacial water fluctuations. Ice movement was caused by a combination of bed deformation and basal sliding.
\end{abstract}

Key words: subglacial till, basal sliding, bed deformation, Dobrzyń Lakeland

\begin{abstract}
Wstęp
Ruch lądolodu po niezamarzniętych nieskonsolidowanych osadach, którego spąg znajduje się w punkcie topnienia, może zasadniczo odbywać się w wyniku poślizgu bazalnego lub deformacji podłoża (por. Evans i in. 2006). W warunkach wysokiego ciśnienia wód subglacjalnych dochodzi do odspojenia lodu od podłoża i jego poślizgu po warstewce wody. Wskutek utraty bezpośredniego kon-
\end{abstract}

taktu z podłożem lód traci możliwość interakcji z osadami, po których się przemieszcza. Natomiast w rezultacie spadku ciśnienia wody subglacjalnej następuje zespolenie lodu z podłożem i rozwój procesów deformacji osadów.

Cechy strukturalne i teksturalne glin subglacjalnych odzwierciedlają złożone procesy depozycyjno-deformacyjne oraz warunki, w jakich były one formowane pod lodem (m.in. Dreimanis 1989, Evans i in. 2006). Zapi- 
sem sedymentologicznym odspojenia lodu od podłoża są przeważnie laminy i warstwy osadów wysortowanych (Piotrowski i in. 2006). Zaś świadectwem zespolenia lodu z podłożem i deformacji osadów są zazwyczaj masywne gliny subglacjalne powstałe $\mathrm{w}$ efekcie zniszczenia pierwotnych cech strukturalnych osadu. Badania terenowe wskazują na powszechność występowania zapisu tych procesów w sekwencjach glin (m.in. Piotrowski i in. 2006, Narloch $i$ in. 2012, Narloch i in. 2013). Dodatkowo analizy sedymentologiczne glin w odsłonięciach, zarówno w profilach pionowych, jak i obocznie, umożliwiają prześledzenie zapisu zmienności czasowo-przestrzennej warunków i procesów subglacjalnych, wskazując na mozaikowy charakter ich występowania pod dawnymi lądolodami (m.in. Piotrowski i in. 2004, Narloch i in. 2013).

Artykuł ma na celu zaprezentowanie zróżnicowania cech sedymentologicznych glin subglacjalnych ostatniego zlodowacenia skandynawskiego w północnej części Pojezierza Dobrzyńskiego oraz ich odniesienie do procesów subglacjalnych i mechanizmów ruchu lodu po podłożu.

\section{Obszar badań}

Stanowiska badawcze są zlokalizowane w czynnych wyrobiskach w obrębie wysoczyzny morenowej (w jej strefie krawędziowej), która w znacznej mierze jest zbudowana z glin lodowcowych (Wysota, Sokołowski 2009). Stanowisko Przeszkoda położone jest około $5 \mathrm{~km}$ na południowy zachód, a stanowisko Obórki około $10 \mathrm{~km}$ na północ, od Rypina (ryc. 1). Głównymi jednostkami geomorfologicznymi badanego obszaru są wysoczyzna morenowa i rynna Rypienicy o orientacji N-S, która dzieli wysoczyznę na dwie morfologicznie różne części. Część wschodnia jest bardziej płaska i wznosi się do $135 \mathrm{~m}$ n.p.m., natomiast część zachodnia jest bardziej falista o wysokości do ponad 150 m n.p.m. (Wysota, Sokołowski 2009).

Osady czwartorzędowe na terenie badań są podścielone ciągłą warstwą utworów mioceńskich (piaski, iły), których miąższość sięga $187 \mathrm{~m}$. Strop serii mioceńskich jest bardzo urozmaicony i występuje na zmiennej wysokości od $68 \mathrm{~m}$ p.p.m. do 125 m n.p.m. W niektórych miejscach na północ od stanowiska Obórki iły mioceńskie sięgają niemal powierzchni terenu (Wysota, Sokołowski 2009). Na osadach miocenu zalega ciągła pokrywa osadów czwartorzędu, których miąższość waha się od kilku metrów w obrębie wyniesień podłoża podczwartorzędowego do ponad $100 \mathrm{~m}$ w kopalnych rynnach i dolinach rzecznych.

W profilu stratygraficznym plejstocenu wydzielono osady zlodowaceń południowopolskich, środkowopolskich i ostatniego zlodowacenia oraz rozdzielające je serie rzeczne. Współczesną powierzchnię wysoczyzny

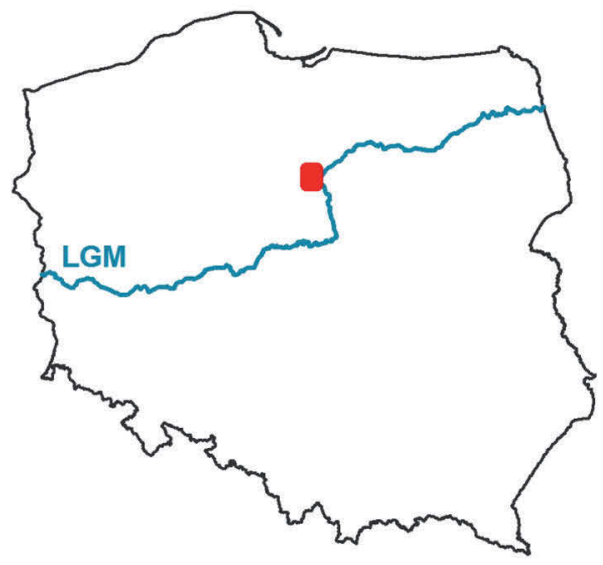

Hipsometria
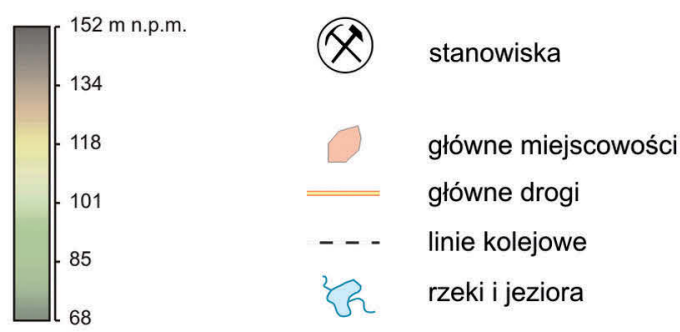

0

$5 \mathrm{~km}$ $19^{\circ} 35^{\prime}$ $19^{\circ} 40^{\prime}$

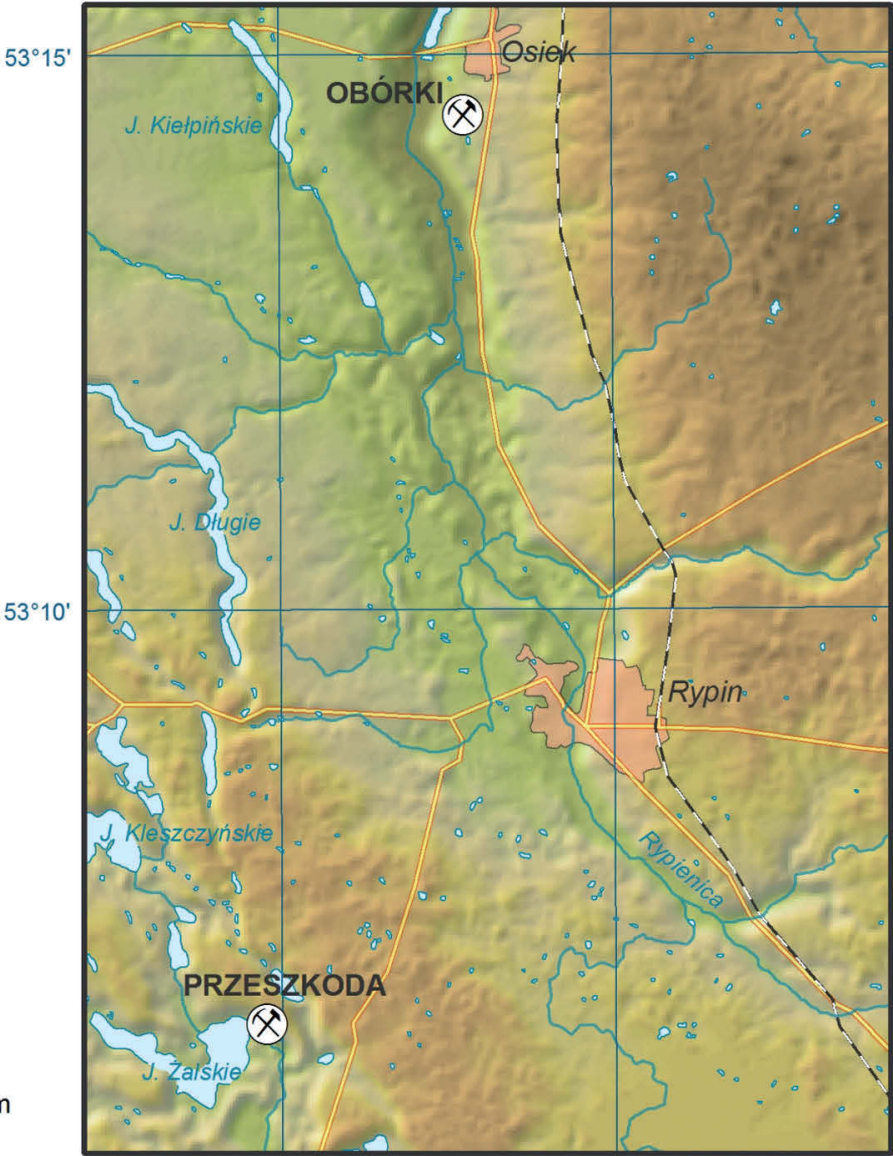

Ryc. 1. Lokalizacja obszaru badań

Fig. 1. Location of the study area 
morenowej w rejonie badań buduje glina zlodowacenia wisły, która na stanowisku Przeszkoda i Obórki jest zaliczana do fazy poznańskiej (Wysota, Sokołowski 2009, Wysota, Molewski 2011).

W szerszym kontekście analizowana glina lodowcowa fazy poznańskiej wiązana jest z rozwojem lobu lodowcowego wisły (Wysota i in. 2009, Wysota, Molewski 2011). W myśl ostatnich badań lob ten był zasilany przez wiślany strumień lodowy, który funkcjonował na linii współczesnej doliny Wisły (Punkari 1997, Boulton i in. 2001, Stokes, Clark 2001, Marks 2002, 2005, 2012, Wysota 2002, 2007, Molewski 2007, Wysota i in. 2009, Roman 2010).

\section{Metody badań}

Na stanowisku Przeszkoda i Obórki analizowana była glina lodowcowa fazy poznańskiej razem ze stropową częścią osadów bezpośrednio ją podścielających (ryc. 2). Przeprowadzono analizę litofacjalną osadów, analizę cech litologiczno-petrograficznych oraz wykonano pomiary dłuższej osi głazików.

W toku analizy na poziomie poszczególnych facji określono struktury sedymentacyjne, skalę jednostek depozycyjnych, typy litofacji oraz kontakty między nimi. Dokonano interpretacji makroskopowych cech glin lodowcowych oraz osadów piaszczystych bezpośrednio je podścielających. Podczas wydzielania litofacji zastosowano kod według klasyfikacji Eylesa i in. (1983).

$\mathrm{W}$ trakcie pracy stosowano procedurę polegającą na zakładaniu w ścianie odsłonięcia ,okienek badawczych” o wymiarach $20 \times 30 \mathrm{~cm} \mathrm{w}$ interwale pionowym co 10 cm (ryc. 2) (por. Piotrowski i in. 2006, Larsen i in. 2007). W „okienkach” dokonano pomiarów dłuższej osi głazików oraz pobrano próbki do analiz laboratoryjnych, tj. analizy uziarnienia, składu petrograficznego oraz analizy mikromorfologicznej glin lodowcowych.

Analiza orientacji głazików w glinach oparta została na pomiarach azymutu i nachylenia ich dłuższej osi. Pomiarów dokonywano na minimum 25 głazikach nie dłuższych niż $10 \mathrm{~cm}$ i o stosunku osi a:b przynajmniej 2:1. W celu określenia natężenia orientacji dłuższych osi głazików zastosowano parametr $\mathrm{S}_{1}$ (wartość własna wektora, Mark 1973).

Osady piaszczyste, mułkowo-piaszczyste oraz frakcje grubsze od $0,01 \mathrm{~mm}$ w glinach analizowano metodą sitową. Natomiast frakcję $<0,01 \mathrm{~mm}$ w glinach badano metodą laserową na urządzeniu Analysette 22 firmy Fritsch. Analizę uziarnienia wykonano łącznie dla 40 próbek osadów. W pracy zastosowano podział na frakcje oraz nazewnictwo według Instrukcji... (2004).

Badania składu petrograficznego żwirów z glin morenowych wykonano według metodyki Państwowego Instytutu Geologicznego (Rzechowski 1971). Analizie poddano 22 próbki glin pobranych ze ścian odsłonięć. W każdej próbce analizowano minimum 300 ziaren żwirowych frakcji 5-10 mm. Zaprezentowano wskaźniki petrograficzne: $\mathrm{O} / \mathrm{K}, \mathrm{K} / \mathrm{W}, \mathrm{A} / \mathrm{B}$ (skały północne: $\mathrm{K}$ - krystaliczne i kwarce; $\mathrm{O}$ - wapienie, dolomity, hupki i piaskowce; $\mathrm{W}$ wapienie i dolomity; A - skały nieodporne na wietrzenie: wapienie i dolomity paleozoiczne; B - skały odporne na wietrzenie: skały krystaliczne, kwarc i piaskowce paleozoiczne).

Analiza mikromorfologiczna glin lodowcowych objęła łącznie 15 próbek o nienaruszonej strukturze ze stanowiska Przeszkoda i Obórki. Próbki te były pobrane w standardowe puszki Kübieny o wymiarach $80 \times 60 \times 40 \mathrm{~mm}$ (Carr 2004). Wszystkie puszki zostały zorientowane horyzontalnie i równolegle do lokalnego kierunku płynięcia lodu wyznaczonego na podstawie pomiarów dłuższych osi
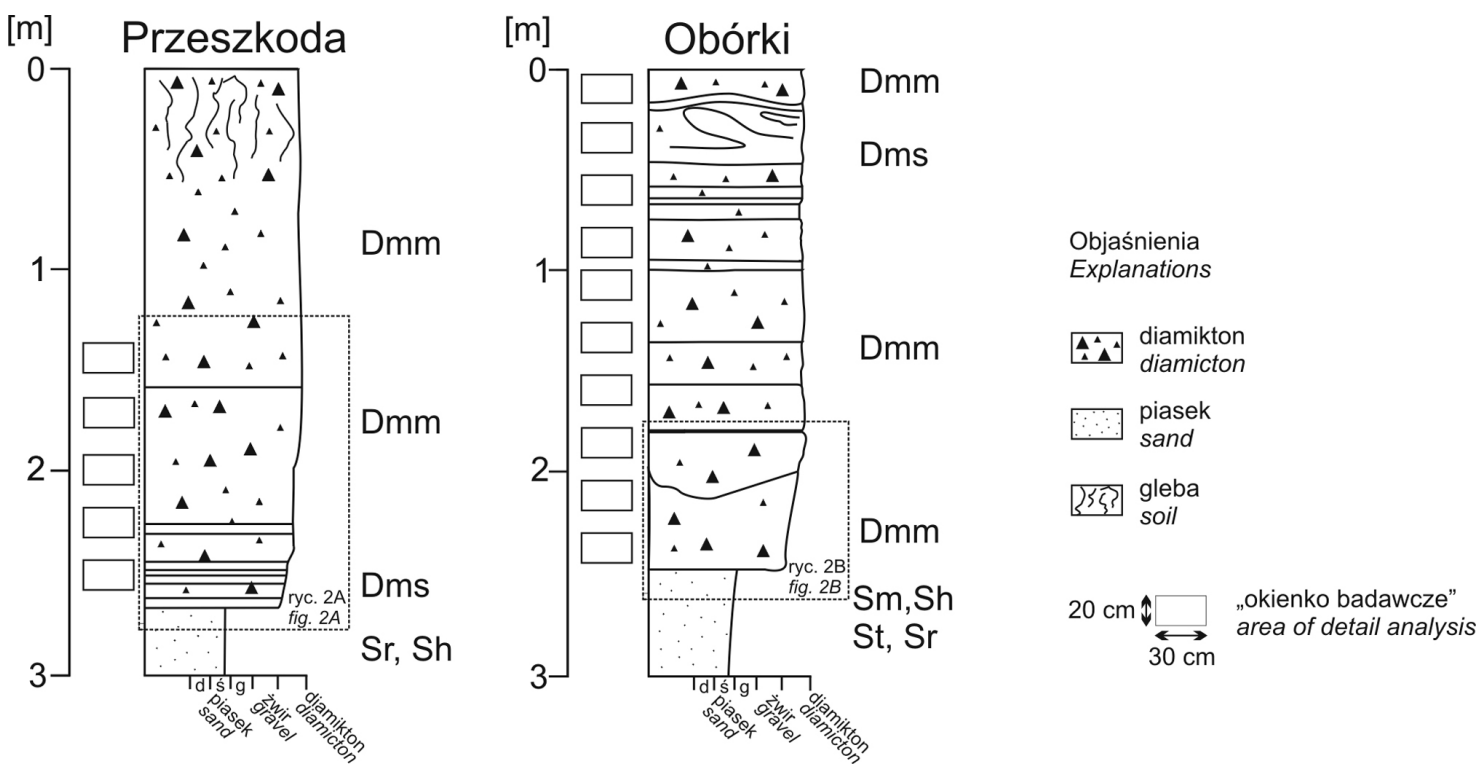

Ryc. 2. Profile litologiczne osadów na stanowisku Przeszkoda i Obórki. Kod litofacjalny według Eylesa i in. (1983)

Fig. 2. Lithological profiles of sediments in the Przeszkoda and Obórki site. Lithofacies code according to Eyles et al. (1983) 
głazików. Analizę szlifów przeprowadzono przy użyciu petroskopu (Kołodziej 1995). Dotyczyła ona wybranych mikrostruktur typu S-matrix będących kombinacją ziaren szkieletu ziarnowego $(>30 \mu \mathrm{m})$ i tzw. plazmy $(<30 \mu \mathrm{m})$, która jest rozumiana jako materiał drobniejszy niż grubość szlifu (van der Meer 1993, Menzies 2000). Mikrostruktury, które były przedmiotem analizy, to: lineacje ziarnowe, pomosty ziarnowe, struktury rotacyjne, pęknięte ziarna, mikroklasty gliniaste oraz domeny (Narloch, Piotrowski 2013).

\section{Wyniki badań}

Na stanowiskach Przeszkoda i Obórki odsłania się profil osadów plejstoceńskich o miąższości sięgającej odpowiednio 10 i $12 \mathrm{~m}$. Badaniami sedymentologicznymi objęto stropowe części profilu, które są reprezentowane przez glinę (ok. 2,5 m miąższości) zaliczaną do fazy poznańskiej ostatniego zlodowacenia (ryc. 2). Ze względu na znaczne podobieństwo sedementologiczne gliny w Przeszkodzie i Obórkach opis wyników analiz cech facjalnych został przedstawiony wspólnie dla obu stanowisk.

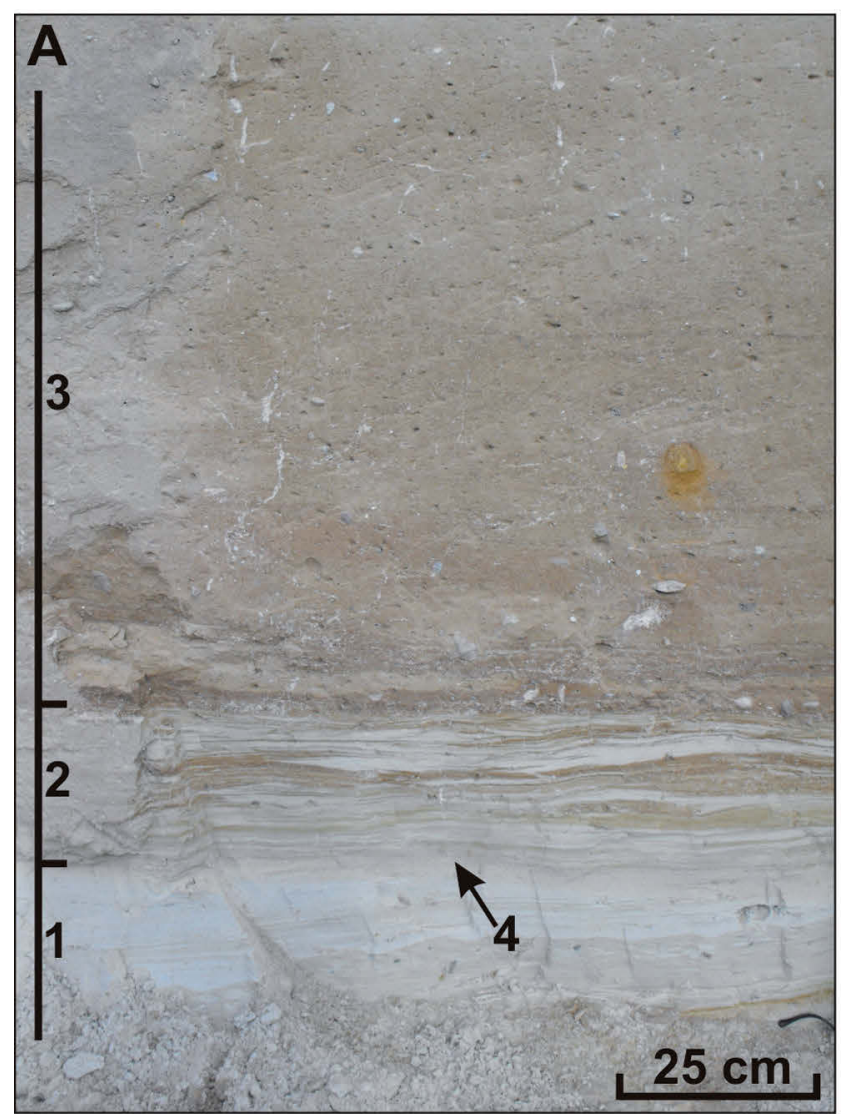

\section{Cechy sedymentacyjne osadów podglinowych}

Osady zalegające bezpośrednio pod gliną lodowcową są zbudowane głównie z piasku drobnego i średniego. Dominują tutaj litofacje o warstwowaniu przekątnym płaskim, przekątnej laminacji riplemarkowej oraz warstwowaniu płaskim. Pomiędzy warstwami przeważają granice erozyjne. W stropie osadów piaszczystych, cechujących się strukturą warstwowania horyzontalnego (stanowisko Przeszkoda) i przekątną laminacją riplemarkową (stanowisko Obórki), bezpośrednio pod gliną lodowcową zaobserwowano drobne fałdki.

\section{Cechy sedymentacyjne gliny lodowcowej}

Warstwę gliny lodowcowej na obu stanowiskach badawczych stanowi diamikton o rozproszonym szkielecie i barwie od jasno- do ciemnobrązowej. Jest to glina cechująca się głównie matriksem piaszczystym, natomiast rzadziej ilastym (ryc. 3). Kontakt warstwy gliny z osadami piaszczystymi jest wyraźny na stanowisku Obórki, natomiast w Przeszkodzie dominuje kontakt przejściowy. W obrębie gliny lodowcowej występują facje wyraźnie warstwowane

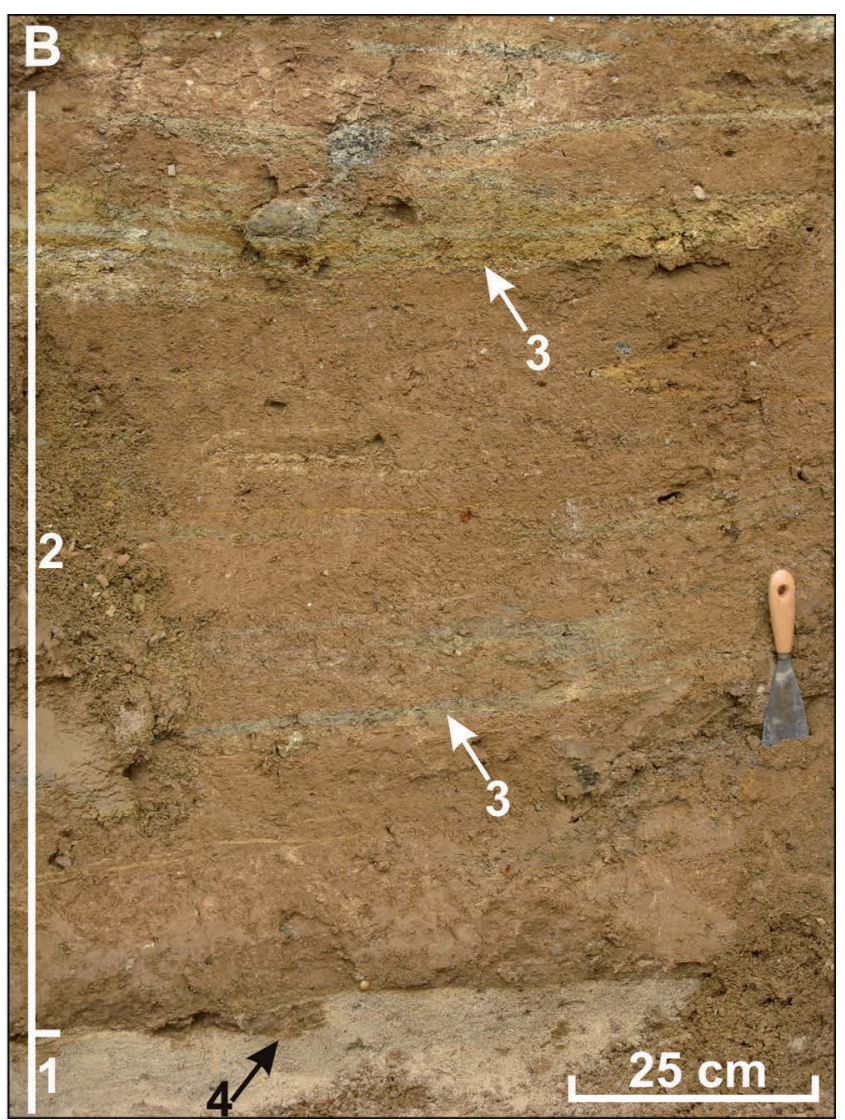

Ryc. 3. Osady badane na stanowiskach terenowych

Stanowisko Przeszkoda (A): 1 - piasek, 2 - glina warstwowana, 3 - glina masywna, 4 - kontakt przejściowy między piaskiem i gliną warstwowaną. Stanowisko Obórki (B): 1 - piasek, 2-glina masywna, 3-zdeformowane fragmenty iłów mioceńskich w glinie masywnej, 4 -ślad płużenia wypełniony gliną. Zwraca uwagę ostry i niezdeformowany kontakt między piaskiem (1) i gliną masywną (2)

Fig. 3. Studied sediments at the field sites

Przeszkoda site (A): 1 - sand, 2 - bedded till, 3-massive till, 4-transitional contact between sand and bedded till. Obórki site (B): 1 - sand, 2 - massive till, 3 - deformed fragments of Miocene clay within massive till, 4 - ploughing marks filled with till. View the sharp and undeformed contact between the sand (1) and the massive till (2) 
oraz masywne o zróżnicowanej pozycji w profilach pionowych (ryc. 2). Obserwowane granice pomiędzy facjami gliny są wyraźne lub przejściowe.

Facje warstwowane o miąższości od 20 do $70 \mathrm{~cm}$ zbudowane są z naprzemianległych masywnych lamin o różnym uziarnieniu i barwie. Przeważają warstewki o grubości do kilku centymetrów, zbudowane z brunatnego diamiktonu. Występują tu również jasnobrązowe i żółte laminy wysortowanego piasku lub drobnego żwiru o miąższości do $1 \mathrm{~cm}$ (ryc. 2, 3A). W obrębie tych warstewek znajdują się drobne klasty iłu oraz mułku. Kontakty pomiędzy warstewkami o różnej litologii są ostre lub przejściowe. Stwierdzono również kliny ze ścinania oraz drobne, spłaszczone fałdki obalone. W diamiktonach warstwowanych występują liczne ślady płużenia z zakorzenionymi głazikami.

Facje masywne obejmują masywny diamikton o miąższości od $25 \mathrm{~cm}$ do 1,3 m (ryc. 2, 3). W ich obrębie zalegają horyzontalne laminy drobnego piasku lub iłu, których grubość sięga kilku milimetrów. Fragmenty warstewek są zaburzone i tworzą struktury fałdków, miejscami silnie spłaszczonych i wyciągniętych. Pomiędzy laminami w masywnym diamiktonie były obserwowane klasty piaszczyste i żwirowe. Na stanowisku Obórki występowały też zdeformowane i rozciągnięte fragmenty iłów mioceńskich (ryc. 3B). Zarówno w glinie masywnej i warstwowanej były stwierdzane ślady płużenia wraz z zapłużonymi głazikami. Niektóre z tych głazików rozrywały laminy osadów wysortowanych.

\section{Orientacja dłuższej osi głazików}

Facje gliny lodowcowej odznaczają się dobrą i bardzo dobrą orientacją dłuższych osi głazików, z wartościami własnymi wektora $\mathrm{S}_{1}$ w przedziale od 0,53 do 0,81 . Ukierunkowanie głazików wskazuje na sektor od NW po NE (Narloch i in. 2012). Dłuższe osie głazików zasadniczo układają się równolegle do lokalnego kierunku płynięcia lodu, natomiast w mniejszym stopniu prostopadle do niego.

\section{Uziarnienie osadów}

W osadach podglinowych wyraźnie dominuje frakcja piaszczysta (powyżej 90\%) nad mułkową (do 10\%). Rozkłady uziarnienia wszystkich facji glin są bimodalne, z modami we frakcji drobnych piasków i mułków. Skład granulometryczny glin przedstawia się następująco: 4153\% piasku, 35-44\% mułku i 10-14\% iłu. We wszystkich warstwach diamiktonowych zawartość żwiru jest niska i mieści się w przedziale od 1 do $4 \%$.

\section{Skład petrograficzny}

Facje glin cechuje podobny udział poszczególnych rodzajów skał (Narloch i in. 2012, Narloch i in. 2013). Skały pochodzenia północnego stanowią średnio 93\%. Wśród nich dominują wapienie północne (średnio 44\%) oraz skały krystaliczne (średnio 41\%). Udział dolomitów wynosi około 3\%. Natomiast zawartość skał lokalnych nie przekracza $10 \%$.

Wartości współczynników petrograficznych są zróżnicowane. W przypadku współczynnika O/K zakres wartości wynosi 0,91-2,04 i jest zazwyczaj większy od pozostałych współczynników. Wartość współczynnika K/W zawiera się w granicach 0,53-1,31. Współczynnik A/B, o zakresie od 0,61 do 1,52, ma wartości mniejsze od współczynnika $\mathrm{O} / \mathrm{K}$ oraz zazwyczaj większe od K/W.

\section{Mikromorfologia}

Spośród analizowanych mikrostruktur typu S-matrix lineacje ziarnowe są najbardziej rozpowszechnione we wszystkich próbkach, gdzie ich zawartość waha się od $30 \%$ do $85 \%$. Długość lineacji sięga kilku milimetrów, a w nielicznych przypadkach nawet $20 \mathrm{~mm}$.

Kolejnymi najczęściej stwierdzanymi mikrostrukturami są pomosty ziarnowe, których orientacja względem lineacji ziarnowych jest najczęściej skośna. Frekwencja tych mikrostruktur zawiera się w przedziale od $9 \%$ do $38 \%$.

Udział struktur rotacyjnych sięga maksymalnie około $15 \%$. Ich wielkość nie przekracza kilku milimetrów. Najczęściej nie mają większego ziarna w swej centralnej części oraz mogą występować w kombinacji z innymi mikrostrukturami (Narloch, Piotrowski 2013).

Mikroklasty gliniaste są zbudowane $\mathrm{z}$ drobniejszego materiału niż otaczający je osad. Ich frekwencja w próbkach jest bardzo zróżnicowana od całkowitego braku po 42-procentowy udział w warstwowanej facji gliny na stanowisku Obórki.

Podobnie przedstawia się sytuacja domen, które są stwierdzane głównie w facjach glin warstwowanych, gdzie ich udział nie przekracza 2\%. Natomiast frekwencja pękniętych ziaren kwarcu najczęściej nie przekracza 13\%.

\section{Interpretacja}

W nawiązaniu do wcześniejszych badań osady podglinowe na stanowisku Przeszkoda należy interpretować jako wodnolodowcowe (Sobieraj 2010), zaś na stanowisku Obórki są to najprawdopodobniej piaski genezy fluwioperyglacjalnej, na co wskazuje podwyższona zawartość ziaren matowych pochodzenia eolicznego oraz występowanie osadów typu wet-eolian (Osowicka 2010, Narloch $i$ in. 2012).

Po depozycji osadów piaszczystych nastąpiło nasunięcie lądolodu z kierunku północnego. Podczas transgresji lądolód eroduje podłoże piaszczyste $\mathrm{i}$ wychodnie iłów mioceńskich, a następnie inkorporuje je w warstwę deformacyjną silnego ścinania subglacjalnego osadów (Narloch i in. 2012). Dochodzi do mieszania się iłów i piasków z uwalnianym materiałem morenowym (dalekiego transportu) ze stopy lądolodu. Procesy deformacji w tej warstwie prowadzą do znacznej homogenizacji osadów (Boulton 1996, Boulton i in. 2001). 
W facjach gliny warstwowanej jej warstewki są zapisem procesów z odkładania (Dreimanis 1989, Evans i in. 2006). Ich kontakt z laminami o innej litologii zazwyczaj ma cechy przejściowe i świadczy o mieszaniu się materiału dalekiego transportu z lokalnym. Wskazuje to na procesy deformacji, jednakże miąższość warstwy deformacyjnej najprawdopodobniej nie przekraczała kilku centymetrów (Tulaczyk 1999, Larsen i in. 2004, Piotrowski i in. 2006, Piotrowski). Procesy ścinania osadów doprowadziły do powstania tzw. laminacji tektonicznej (Benn, Evans 1996, Boulton i in. 2001). Wskazują na to kontakty przejściowe pomiędzy poszczególnymi warstewkami (m.in. Weertman 1968) oraz struktury klinów ze ścinania. Natomiast wyraźne granice pomiędzy warstewkami piasku a diamiktonem świadczą o depozycji w odspojeniach lodu od podłoża i poślizgu bazalnym po cienkiej warstewce wody (Alley 1989, Piotrowski, Tulaczyk 1999, Piotrowski i in. 2006). W warunkach wysokiego ciśnienia wód porowych zachodziły także procesy płużenia oraz towarzyszące im deformacje o cechach podatnych (Tulaczyk 1999). Warstwowane diamiktony to efekt procesów z odłożenia, deformacji (ścinania) oraz płużenia (Narloch $i$ in. 2012, Narloch $i$ in. 2013).

Formowanie się glin masywnych było również procesem złożonym, na który składały się: depozycja z odłożenia, deformacja oraz płużenie. Wraz ze wzrostem miąższości gliny powstawały warunki utrudnionego drenażu wód subglacjalnych i w konsekwencji stopniowego wzrostu ciśnienia wód porowych (Iverson i in. 1995, Hoffman, Piotrowski 2001, Piotrowski i in. 2006). Na skutek równoważenia ciśnienia nadległych mas lądolodu przez ciśnienie wód porowych dochodziło do odspajania lodu od podłoża (Munro-Stasiuk 2000) i jego poślizgu po warstewce wody (Alley 1989, Piotrowski, Tulaczyk 1999, Piotrowski i in. 2006). W warunkach tych zachodziły także procesy płużenia, którym towarzyszyła deformacja osadów (Tulaczyk 1999). W trakcie okresowego odspajania lodu od podłoża dochodziło do depozycji drobnych warstewek piaszczystych. Potem w wyniku drenażu spadało ciśnienie wody subglacjalnej i następowało ponowne zespolenie lodu z podłożem. Horyzontalne laminy piaszczyste świadczą o kilkakrotnym powtarzaniu się tego cyklu. Po każdorazowym spadku ciśnienia i depozycji świeżo uwalnianego materiału morenowego znów następował rozwój warstwy deformacyjnej (Narloch i in. 2012). Wskazuje to na sukcesywną migrację strefy deformacji ku górze jednostki gliny morenowej (Larsen i in. 2004). Stwierdzone deformacje lamin piasku są najprawdopodobniej zapisem tego mechanizmu.

Mikrostruktury we wszystkich analizowanych profilach prezentują deformacje o cechach kruchych (lineacje ziarnowe) i podatnych (struktury rotacyjne). Lineacje ziarnowe wskazują na procesy ścinania osadów (m.in. Menzies i in. 2006, Thomason, Iverson 2006). Występowanie obok siebie struktur deformacji kruchych i podatnych było zapewne uwarunkowane strefami o zróżnicowanym ciśnieniu wód porowych (m.in. van der Meer i in. 2003). Natomiast współwystępowanie różnych struktur wynikało przypuszczalnie z cyklicznego przechodzenia diamiktonu ze stanu upłynnienia do stanu bardziej skonsolidowanego i odwrotnie (Evans i in. 2006, Narloch $i$ in. 2012, Narloch i in. 2013).

\section{Dyskusja}

Analizowane gliny są przeważnie piaszczyste, o strukturze masywnej. Występują w nich klasty o różnej litologii (od iłu po piasek) oraz horyzontalne warstewki wysortowanych osadów piaszczystych i ilastych. Natomiast diamiktony warstwowane cechują się mniejszą miąższością w porównaniu z glinami masywnymi.

Jak wcześniej stwierdzono, cechy sedymentologiczne glin wskazują na ich złożoną genezę. Dominującą rolę w procesach depozycji i deformacji glin odgrywała ilość wody w podłożu lądolodu. Pochodziła ona głównie z topnienia bazalnego wywołanego przez dopływ ciepła geotermalnego i tarcie o podłoże (Paterson 1994). Aby glina mogła być deformowana, ciśnienie porowe wody musi osiągnąc przynajmniej 90-95\% wartości ciśnienia nadległych mas lodu i osadu (Paterson 1994). Kiedy ciśnienie wód subglacjalnych osiągnie punkt podniesienia hydraulicznego, dochodzi do odspojenia lodu od podłoża, co hamuje rozwój deformacji podłoża (m.in. Iverson i in. 1995, Munro-Stasiuk 2000, Jørgensen, Piotrowski 2003, Piotrowski i in. 2006). Najprawdopodobniej w początkowej fazie nasuwający się lądolód wkraczał na obszar występowania wieloletniej zmarzliny, której obecność mogła stanowić czynnik utrudniający drenaż wody i w konsekwencji wzrost ciśnienia subglacjalnego (Hughes 1992, Narloch i in. 2013).

Duża zawartość skał północnych w diamiktonach sugeruje przewagę procesów depozycji z odłożenia materiału transportowanego głównie wewnątrz lądolodu (m.in. Jørgensen, Piotrowski 2003). Podczas tego procesu ciśnienie wód subglacjalnych wielokrotnie ulegało wahaniom (ryc. 4). W warunkach niskiego ciśnienia wód porowych zachodziły procesy uwalniania i odkładania materiału morenowego oraz deformacji miękkich osadów podłoża (ryc. 4I). Wraz ze wzrostem ciśnienia następował spadek tarcia wewnętrznego w diamiktonie oraz na jego kontakcie z lodem bazalnym. Na tym etapie zaznaczał się wzrost znaczenia poślizgu bazalnego w ruchu lodu (ryc. 4I).

Dalszy wzrost ciśnienia wody subglacjalnej prowadził do osiągnięcia punktu hydraulicznego podniesienia lodu, po którego przekroczeniu następowało odspojenie stopy lądolodu od podłoża (ryc. 4II, III). Fluktuacje ciśnienia powodowały cykliczne odspajanie i zespalanie stopy lodu i podłoża. Wynikało to najprawdopodobniej z okresowo zmieniających się warunków drenażu wody subglacjalnej (łatwiejszego lub utrudnionego) lub topnienia lodu bazalnego (bardziej lub mniej wydajnego) (ryc. 4II). Podczas odspojenia lodu od podłoża następował poślizg lądolodu po warstewce wody, gdzie jednocześnie dochodziło do depozycji osadów wysortowanych, głównie piasków i żwirów. Natomiast deformacja osadów podłoża mogła zachodzić w wyniku procesów płużenia. 
Spadek ciśnienia wody prowadził do ponownego zespolenia lodu z podłożem i rozwoju procesów deformacji. W warunkach ciśnienia wód subglacjalnych oscylującego wokół poziomu hydraulicznego podniesienia lodu następowały procesy depozycji gliny, deformacji ze ścinania i formowania się laminacji tektonicznej (ryc. 4II). W przypadku utrzymywania się przez dłuższy czas ciśnienia wód powyżej punktu hydraulicznego podniesienia lodu (w sytuacji utrudnionego drenażu), funkcjonujące w tej fazie odspojenia mogły stanowić miejsce sedymentacji drobnych osadów ilastych (ryc. 4III). W tych warunkach dominował poślizg lodu bazalnego po warstewce wody. Powolny spadek ciśnienia na skutek utrudnionego drenażu wód subglacjalnych umożliwiał rozwój procesów płużenia. Jedynie klasty większe niż miąższość warstwy wody mogły powodować deformacje osadów podłoża. Gdy dochodziło do zamykania się odspojeń, następowała depozycja masywnego diamiktonu. Jednak panujące nadal wysokie ciśnienie wód porowych umożliwiało rozwój deformacji (ryc. 4III). W tej fazie mogło dochodzić powszechnie do szybkiego ruchu lodu głównie na skutek poślizgu bazalnego.

\section{Podsumowanie}

Wydzielone i analizowane w profilach facje diamiktonowe wskazują na ich złożoną genezę. Stanowią one zapis kombinacji procesów depozycji z odłożenia oraz szeroko rozumianej deformacji subglacjalnej. Interpretowane są jako subglacjalne gliny hybrydowe, które w klasyfikacji glin Evansa i in. (2006) określane są jako subglacial traction tills.

Po wkroczeniu lądolodu na obszar północnej części Pojezierza Dobrzyńskiego obecność wody w osadach odgrywała zasadniczą rolę w procesach formowania glin oraz mechanizmach ruchu lodu po podłożu. W warunkach wysokiego ciśnienia wody dochodziło do odspajania lodu od podłoża i poślizgu po warstewce wody, czego zapisem sedymentologicznym są warstwowane diamiktony. Gdy ciśnienie porowe wód spadało, dochodziło do ponownego zespolenia lodu i podłoża, co skutkowało rozwojem warstwy deformacyjnej.

Warunki subglacjalne (m.in. budowa geologiczna podłoża, ciśnienie wody subglacjalnej) na kontakcie lód/ podłoże prowadziły do okresowego powstawania stref

Poślizg bazalny
Basal sliding

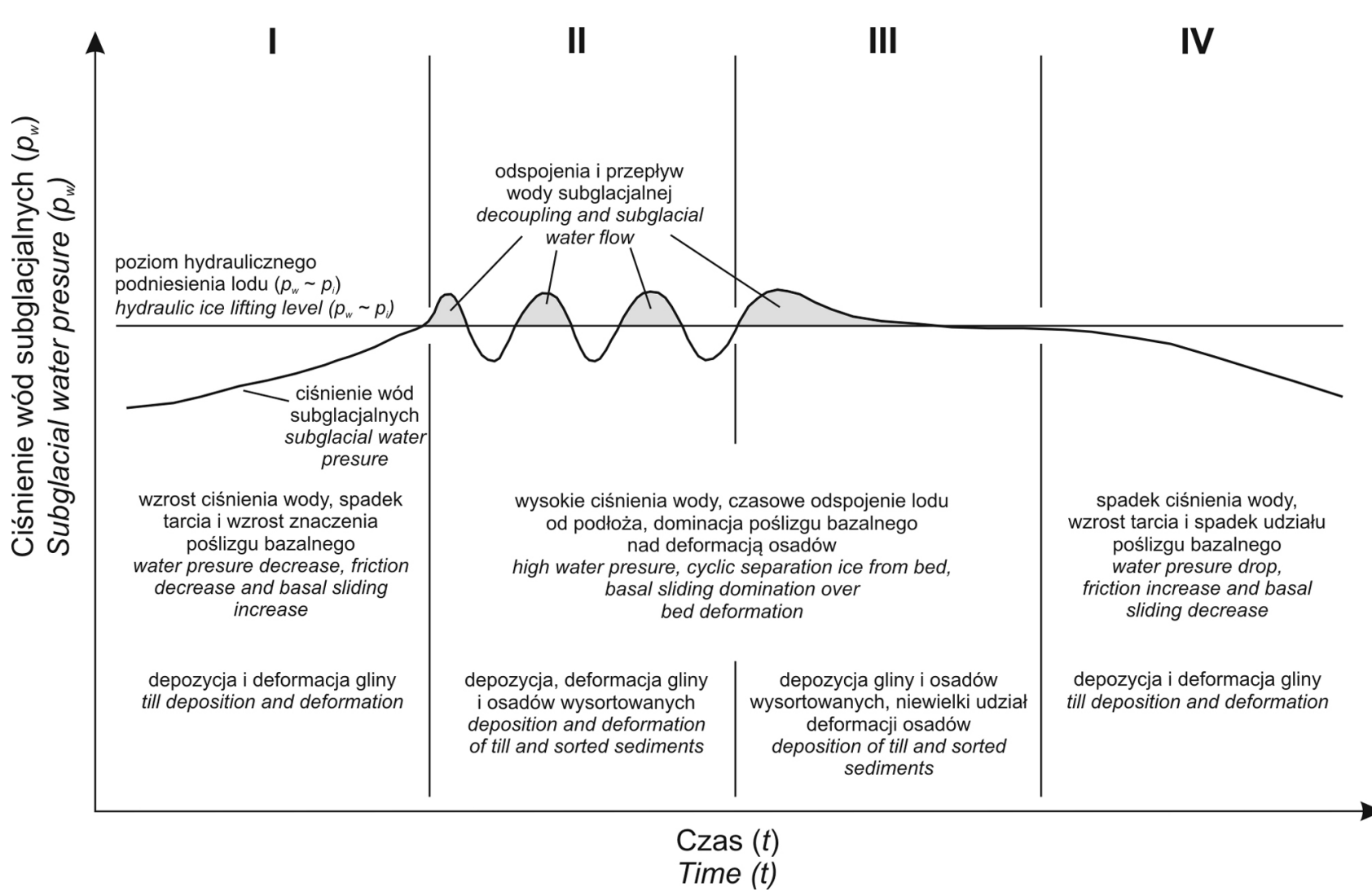

Ryc. 4. Model formowania glin subglacjalnych na stanowisku Przeszkoda i Obórki w odniesieniu do fluktuacji ciśnienia wód subglacjalnych (wg Jørgensen, Piotrowski 2003 - zm.). Fazy formowania glin od I do IV mogą występować w różnej kolejności

Fig. 4. Model of subglacial till formation in the Przeszkoda and Obórki site in accordance to subglacial water fluctuations (according to Jørgensen, Piotrowski 2003 - modified). Till formation phases from I to IV may occur in different order 
bardziej i mniej stabilnego podłoża. Przemawia to za modelem Piotrowskiego i in. (2004), w którym obszary deformacji podłoża pod stopą lądolodu tworzyły mozaikę, podlegającą reorganizacji w czasie i przestrzeni.

Ponadto zaprezentowane $\mathrm{w}$ artykule wyniki badań odnoszące się do procesów depozycji i deformacji glin subglacjalnych dają asumpt do szerszej dyskusji dotyczącej dynamiki brzeżnych stref lądolodów, w szczególności dawnych strumieni lodowych i wypustowych lobów lodowcowych na obszarach ostatniego zlodowacenia plejstoceńskiego.

\section{Podziękowania}

Badania były finansowane ze środków: Funduszu Społecznego i Budżetu Państwa w ramach Zintegrowanego Programu Operacyjnego Rozwoju Regionalnego, działania 2.6 ,Regionalne Strategie Innowacyjne i Transfer Wiedzy" projektu własnego województwa kujawsko-pomorskiego „Stypendia dla doktorantów 2008/2009 - ZPORR” (W. Narloch); grant UMK nr 363-G (W. Wysota, W. Narloch); Danish Agency of Science, Technology and Innovation, FNU grant nr 09-062326 (J.A. Piotrowski).

\section{Literatura}

Alley R.B., 1989. Water pressure coupling of sliding and bed deformation. II. Velocity-depth profiles. Journal of Glaciology 35: 119-129.

Benn D.I., Evans D.J.A., 1996. The interpretation and classification of subglacially-deformed materials. Quaternary Science Reviews 15: 23-52.

Boulton G.S., 1996. Theory of glacial erosion, transport and deposition as a consequence of subglacial sediment deformation. Journal of Glaciology 42: 43-62.

Boulton G.S., Dongelmans P., Punkari M., Broadgate M., 2001. Palaeoglaciology of an ice sheet through a glacial cycle: the European ice sheet through the Weichselian. Quaternary Science Reviews 20: 591-625.

Carr S.J., 2004. Micro-scale features and structures. W: D.J.A. Evans, D.I. Benn (red.), A practical guide to the study of glacial sediments. Arnold, London: 115-144.

Dreimanis A., 1989. Tills: their genetic terminology and classification. W: R.P. Goldtwait, C.L. Matsch (red.), Genetic classification of glacigenic deposits. A.A. Balkema, Rotterdam: 17-83.

Evans D.J.A., Phillips E.R., Hiemstra J.F., Auton C.A., 2006. Subglacial till: formation, sedimentary characteristics and classification. Earth Science Reviews 78: 115-176.

Eylse N., Eylse C.H., Miall A.D., 1983. Litofacies types and vertical profile models; an alternative approach to the description and environmental interpretation of glacial diamict and diamictite sequences. Sedimentology 30: 393-410.

Hoffmann K., Piotrowski J.A., 2001. Till melange at Amsdorf, central Germany: sediment erosion, transport and deposition in a complex, soft-bedded subglacial system. Sedimentary Geology 140: 215-234.

Hughes T., 1992. Abrupt climatic change related to unstable ice-sheet dynamics: toward a new paradigm. Palaeogeography, Palaeoclimatology, Palaeoecology 97: 203-234.

Instrukcja w sprawie opracowania i wydania szczegółowej mapy geologicznej Polski w skali 1:50 000. 2004. Wyd. Geol., Warszawa.

Iverson N.R., Hanson B., Hooke R.LeB., Jansson P., 1995. Flow mechanism of glaciers on soft beds. Science 267: 80-81.

Jørgensen F., Piotrowski J.A., 2003. Signature of the Baltic Ice Stream on Funen Island, Denmark during the Weichselian glaciation. Boreas 32: $242-255$.
Kołodziej G., 1995. Petroskop - nowe możliwości prezentacji wizualnej. Przegląd Geologiczny 43(11): 952-953.

Larsen N.K., Piotrowski J.A., Kronborg C., 2004. A multiproxy study of basal till: a time transgressive accretion and deformation hypothesis. Journal of Quaternary Science 19: 9-21.

Larsen N.K., Piotrowski J.A., Menzies J., 2007. Microstructural evidence of lowstrain, time-transgressive subglacial deformation. Journal of Quaternary Science 22: 593-608.

Mark D.M., 1973. Analysis of axial orientation data, including till fabrics. Geological Society of America Bulletin 84: 1369-1374.

Marks L., 2002. Last Glacial Maximum in Poland. Quaternary Science Reviews 21: 103-110.

Marks L., 2005. Pleistocene glacial limits in the territory of Poland. Przegląd Geologiczny 53: 988-993.

Marks L., 2012. Timing of the Late Vistulian (Weichselian) glacial phases in Poland. Quaternary Science Reviews 44: 81-88.

Menzies J., 2000. Micromorphological analyses of microfabrics and microstructures indicative of deformation processes in glacial sediments. W: A.J. Maltman, B. Hubbard, M.J. Hambrey (red.), Deformation of glacial materials. Geological Society Special Publication 176, London: 245-257.

Menzies J., van der Meer J.J.M., Rose J., 2006. Till - a glacial “tectomict", a microscopic examination of a till's internal architecture. Geomorphology 75: 172-200.

Molewski P., 2007. Neotektoniczne i glacidynamiczne uwarunkowania wykształcenia plejstocenu Wysoczyzny Kujawskiej. Wyd. Nauk. UMK, Toruń.

Munro-Stasiuk M.J., 2000. Rhytmic till sedimentation: evidence for repeated hydraulic lifting of a stagnant ice mass. Journal of Sedimentary Research 70: 94-106.

Narloch W., Piotrowski J.A., 2013. Mikromorfologia glin lodowcowych jako narzędzie w rekonstrukcji procesów subglacjalnych. Przegląd Geologiczny 61(5): 194-303.

Narloch W., Piotrowski J.A., Wysota W., Larsen N.K., Menzies J., 2012. The signature of strain magnitude in tills associated with the Vistula Ice Stream of the Scandinavian Ice Sheet, central Poland. Quaternary Science Reviews 57: 105-120.

Narloch W., Wysota W., Piotrowski J.A., 2013. Sedimentological record of subglacial conditions and ice sheet dynamics of the Vistula Ice Stream (north-central Poland) during the Last Glaciation. Sedimentary Geology 293: 30-44.

Osowicka A., 2010. Głazy rzeźbione przez wiatr w stanowisku Obórki koło Rypina: dowód i implikacje działalności wiatru w dawnej strefie peryglacjalnej. MS, Arch. UMK, Toruń.

Paterson W.S.B., 1994. The physics of glaciers. 3rd ed. Pergamon, Oxford.

Piotrowski J.A., Larsen N.K., Junge F.W., 2004. Reflections on soft subglacial beds as a mosaic of deforming and stable spots. Quaternary Science Reviews 18: 737-751.

Piotrowski J.A., Larsen N.K., Menzies J., Wysota W., 2006. Formation and subglacial till under transient bed conditions: deposition, deformation, and basal decoupling under Weichselian ice sheet lobe, central Poland. Sedimentology 53: 83-106.

Piotrowski J.A., Tulaczyk S., 1999. Subglacial conditions under the last ice sheet in northwest Germany: ice-bed separation and enhanced basal sliding? Quaternary Science Reviews 18: 737-751.

Punkari M., 1997. Glacial and glaciofluvial deposits in the interlobate areas of the Scandinavian Ice Sheet. Quaternary Science Reviews 16: 741-753.

Roman M., 2010. Rekonstrukcja lobu płockiego w czasie ostatniego zlodowacenia. Acta Geographica Lodzensia 96.

Rzechowski J., 1971. Granulometryczno-petrograficzne właściwości glin zwałowych w dorzeczu środkowej Widawki. Biuletyn Instytutu Geologicznego 254: 111-155.

Sobieraj J.M., 2010. Właściwości teksturalne, skład petrograficzny żwirów oraz eratyki przewodnie i wskaźnikowe gliny subglacjalnej lobu Wisły w stanowisku Przeszkoda w okolicy Rypina. MS, Arch. UMK, Toruń.

Stokes C.R., Clark C.D., 2001. Palaeo-ice streams. Quaternary Science Reviews 20: 1437-1457.

Thomason J.F., Iverson N.R., 2006. Microfabric and microshear evolution in deformed till. Quaternary Science Reviews 25: 1027-1038. 
Tulaczyk S., 1999. Ice sliding over weak, fine-grained tills: dependence of ice-till interactions on till granulometry. W: D.M. Mickelson, J.W. Attig (red.), Glacial Processes: Past and Present. Geological Society of America, Special Paper 337: 159-177.

van der Meer J.J.M., 1993. Microscopic evidence of subglacial deformation. Quaternary Science Reviews 12: 553-587.

van der Meer J.J.M., Menzies J., Rose J., 2003. Subglacial till, the deformable glacier bed. Quaternary Science Reviews 22: 1659-1685.

Weertman J., 1968. Diffusion law for the dispersion of hard particles in an ice matrix that undergoes simple shear deformation. Journal of Glaciology 7: 161-165.

Wysota W., 2002. Stratygrafia i środowiska sedymentacji zlodowacenia wisły w południowej części dolnego Powiśla. Wyd. UMK, Torun.
Wysota W., 2007. Successive subglacial depositional processes as interpreted from basal tills in the Lower Vistula valley (N Poland). Sedimentary Geology 193: 21-31.

Wysota W., Molewski P., 2011. Chronologia i zasięgi nasunięć lądolodu na obszarze lobu Wisły podczas stadiału głównego ostatniego zlodowacenia. Przegląd Geologiczny 59(3): 214-225.

Wysota W., Molewski P., Sokołowski R.J., 2009. Record of the Vistula ice lobe advances in the Late Weichselian glacial sequence in north-central Poland. Quaternary International 207: 26-41.

Wysota W., Sokołowski R., 2009. Objaśnienia do Szczegółowej mapy geologicznej Polski w skali 1:50 000, ark. Rypin. Centr. Arch. Geol., PIG-PIB, Warszawa. 